\title{
SISTEM ISOLASI DAN BUKA ISOLASI OTOMATIS PADA SENTRAL TELEPON AT\&T
}

\author{
Nanang Ruswianto', Fazmah Arif Yulianto², Heri Kurniawan ${ }^{3}$ \\ ${ }^{1,2}$ Jurusan Teknik Informatika - Sekolah Tinggi Teknologi Telkom, Bandung \\ ${ }^{3}$ Telkom Divre III, Bandung \\ ${ }^{1}$ bumenmania@plasa.com, ${ }^{2}$ fay@stttelkom.ac.id, ${ }^{3}$ herik@divre3.telkom.co.id
}

\begin{abstract}
Abstrak
Pelanggan telepon yang menunggak membayar tagihan sampai jangka waktu tertentu akan mendapat sanksi berupa isolasi sambungan teleponnya. Status isolasi ini menyebabkan sambungan telepon tidak dapat melakukan panggilan. Sambungan akan kembali seperti kondisi normal setelah kewajiban pembayaran tagihan dan denda dipenuhi. Status tiap sambungan telepon tersimpan di sentral. Pengeksekusian perintah (manajemen) sentral telepon umumnya masih melibatkan bisnis proses manual yang rumit dan cenderung kurang efisien. Dalam tulisan ini diusulkan perbaikan bisnis proses isolasi dan buka isolasi sentral telepon type AT\&T (5ESS) dengan menggunakan bantuan PC. Sistem yang diberi nama SOPST (Sistem Otomatisasi Pengisolasian Sentral Telepon) secara otomatis akan melakukan pengecekan pada database pelanggan telepon. Jika ditemui keadaan yang mengharuskan perubahan status sambungan telepon (isolasi maupun buka isolasi), sistem akan langsung mengubah status pelanggan pada sentral. Dengan adanya sistem baru ini diharapkan proses pengisolasian di PT Telkom dapat dilakukan secara otomatis tiap bulan. Sementara proses buka isolasi dapat disesuaikan dengan komitmen Telkom untuk melakukan buka isolasi dua jam setelah ada informasi pembayaran tunggakan. Dari evaluasi yang dilakukan, diperoleh hasil bahwa dengan menggunakan SOPST mampu menghemat waktu proses sampai $97 \%$, mampu mengeksekusi perintah isolasi dan buka isolasi dengan tingkat kesalahan sebesar $0 \%$ (dengan penanganan beberapa kasus error), serta memiliki tingkat flesibilitas dan pelaporan yang baik serta mampu menyampaikan informasi yang jelas kepada operator.
\end{abstract}

Kata Kunci: isolasi, buka isolasi, otomatis, SOPST, AT\&T

\section{Abstract}

If the telephone bill has not been paid for some pre-defined period, the subscriber will be blocked. The line will operate as normal as before, when the bill plus penalty has been paid. Status of each subscriber line stored inside the telephone switch. Generally, executing telephone central command still involves complicated manual bussines process and tends to be inefficient. This paper propose a system to improve the blocking and unblocking business process for AT\&T (5ESS) telephone switch using PC. This system, called SOPST (Sistem Otomatisasi Pengisolasian Sentral Telepon), will automatically check the subscribers database. Everytime it found conditions which trigger subscriber status change, the system will then alter subscriber status stored inside the telephone switch. Using this new system, Telkom's blocking process will be accomplished automatically every month. Meanwhile, the unblocking process will comply with Telkom's commitment to unblock the blocked telephone number at least two hours after the bill has been paid. The evaluation shows that SOPST can save processing time up to $97 \%$, execute the commands with error rate $0 \%$ (handle several error cases), along with high flexibility and good reporting.

Keywords: blocking, unblocking, automatic, SOPST, AT\&T

\section{Pendahuluan}

Saat ini mekanisme isolasi dan buka isolasi pelanggan telepon di PT Telkom masih dilakukan secara manual, yaitu dengan melibatkan dua dinas yang berbeda, yaitu: dinas teknik dan bagian keuangan. Proses bisnis yang berjalan adalah:

a. setiap akhir bulan bagian keuangan akan melakukan sorting pelanggan telepon yang terlambat dalam melunasi tagihan teleponnya.

b. data tersebut diserahkan ke bagian subdin sentral sebagai bagian dari dinas teknik untuk dilakukan eksekusi isolasi.

c. untuk kasus buka isolasi, petugas subdin sentral menerima data pelanggan setiap 2 jam, untuk kemudian dilakukan pengubahan status pelanggan pada sentral.

Mencermati proses bisnis di atas, terdeteksi adanya masalah yang mungkin muncul, yaitu :

a. kerawanan dalam pengubahan status isolasi dan buka isolasi karena faktor human error.

b. belum adanya mekanisme kontrol otomatis pada sentral telepon yang khusus menangani masalah kehandalan proses isolasi dan buka isolasi.

c. mekanisme yang ada dan digunakan sekarang belum menjamin real-timeness, terutama proses buka isolasi yang seharusnya dilakukan maksimal dua jam setelah pelanggan membayar tunggakan.

Pada penelitian ini dibangun sistem (perangkat lunak) SOPST yang akan dapat meminimalkan 
kemungkinan terjadinya human error, menjamin terlaksananya setiap proses dalam batas waktu yang ditetapkan (proses isolasi sekali tiap bulan, proses buka isolasi dilakukan tiap dua jam), serta mampu menangani kejadian kegagalan pada sentral dan jaringan dengan menjamin integritas dan meminimalkan interfensi manusia, serta dapat menyusun laporan tentang aktifitas yang dilakukan.

Mengawali pembuatan perangkat lunak, dilakukan pengamatan kondisi lapangan dan prosedur manual yang dilakukan selama ini. Hasil survey menunjukkan bahwa mungkin ditambahkan suatu perangkat lunak yang akan berkomunikasi langsung dengan SOPP (penyimpan database pelanggan) dan sentral telepon, sehingga tidak lagi diperlukan campur tangan operator dalam proses isolasi dan buka isolasi. Dengan sistem terkomputerisasi ini diharapkan proses isolasi dan buka isolasi dapat selalu dilakukan tepat waktu.

Selanjutnya ditentukan mekanisme pembacaan data dari SOPP yang secara geografis terpisah cukup jauh (SOPP ada di Kandatel Bandung Jl. Lembong) dan database yang bersifat rahasia. Komunikasi dengan sentral AT\&T tidak terlalu sukar, karena telah tersedia bahasa untuk manajemen sentral. Setelah SOPST jadi, dilakukan pengujian pertama dengan menggunakan emulator sentral. Setelah semua fungsi berjalan dengan baik, barulah dilakukan pengujian kedua pada sistem sebenarnya. Catatan waktu proses manual (untuk dua bulan) kemudian akan dibandingkan dengan kecepatan proses menggunakan SOPST.

Sementara ini, sistem yang dibangun dirancang untuk menangani satu wilayah kerja STO. Pengujian menggunakan database dummy, mengingat tidak mungkin melakukan percobaan dengan nomor telepon operasional.

\section{Tinjauan Umum Sentral Telepon}

Secara garis besar, fungsi-fungsi yang harus diselenggarakan oleh sentral telepon adalah fungsi switching, kontrol panggilan, operasi dan pemeliharaan, antar muka transmisi dan pensinyalan, serta fungsi pensinyalan

\subsection{Struktur Sentral AT\&T 5ESS}

Di dalam sentral 5ESS terdapat Switching Module (SM) yang berhubungan dengan Communication Module (CM) dan berinteraksi dengan Administrative Module (AM). SM merupakan terminasi saluran pelanggan dan sirkit trunk, switching digital time slot (mengubah menjadi sinyal digital). CM menyediakan layanan komuniksi message antara AM \& SM dan antar SM serta menyediakan koneksi path voice dari SM. AM berfungsi mengontrol routing antar modul panggilan, sistem maintenance, antar muka dengan sistem pendukung operasi, antar muka dengan personal maintenance dan backup program serta database.
Pada sentral 5ESS, perangkat lunak dibagi dalam lima fungsi utama: Perangkat Lunak Sistem Operasi, Pengolahan Panggilan, Pelayanan Administrasi, Manajemen Database, dan perangkat lunak Maintenance.

\subsection{Komunikasi Sistem dan Operator Sentral}

Secara umum komunikasi antara operator dengan sistem sentral AT\&T dapat dikatakan sebagai suatu rangkaian transaksi atau dialog yang timbal balik. Dimana setiap command selalu akan direspon oleh sistem. Baik yang bisa dilaksanakan ataupun ditolak. Pada sentral AT\&T MML (Man Machine Language) digunakan untuk berkomunikasi (melakukan transaksi) antara petugas sentral dengan sistem sentral dalam melaksanakan fungsi pemeliharan, instalasi dan pengetesan. Keluaran merupakan reaksi sistem setelah menerima perintah atau pesan dari sistem jika terdeteksi adanya kelainan sistem switching.

\subsection{Bahasa Perintah}

Dalam melakukan dialog / transaksi diperlukan bahasa perintah tertentu yang telah dikenali oleh sistem dan harus diinputkan pada terminal operasi dan pemeliharaan (OMT) sesuai dengan tugas yang diinginkan. Pada sentral jenis AT\&T digunakan TLWS (Trunk Line Work Station) sebagai terminal antarmuka pengaksesan sentral secara lokal Sebuah perintah dimulai dengan kode perintah yang menggambarkan fungsi atau proses yang akan dilaksanakan sistem, dan selanjutnya jika diperlukan informasi tambahan akan diikuti dengan blok parameter. Separator yang digunakan disini adalah tanda ": " (titik dua), tanda ", " (koma), dan tanda “;” (titik koma).

Format perintah pada sentral AT\&T adalah sebagai berikut :

$<$ action $>$-<object $>$ : $<$ parameter $>=<$ value $>, \ldots$,

$<$ parameter $>=<$ value $><$ termination character $>$

\section{Deskripsi Masalah dan Perancangan Sistem}

\subsection{Deskripsi Sistem Isolasi}

Pengisolasian secara administratif dapat dibagi menjadi dua jenis :

a. Isolasi pasif (arah kirim), mulai dieksekusi jika pelanggan menunggak selama satu bulan

b. Isolasi total (arah kirim dan terima), mulai dieksekusi jika pelanggan menunggak selama tiga bulan

Proses isolasi dimulai dari dikeluarkannya data oleh loket penagihan tiap tanggal 30 - 31 setiap bulannya. Data ini biasanya berupa softcopy yang sebelumnya telah disortir oleh petugas penagihan. Data yang berisi daftar nomor telepon yang belum dibayar tagihannya tersebut diserahkan kepada bagian keuangan operator sentral telepon. Operator kemudian akan mengeksekusi perintah isolasi pada 
sentral untuk setiap nomor telepon dalam daftar, sebagai berikut:

(misal nomor telepon yang akan diisolasi: 7500835)

- Isolasi pasif :

<updb-sbldn:dirn=7500835, or=y;

- Isolasi total :

<updb-sbldn:dirn=7500835, or=y,ter=y;

Urutan proses ini terlihat pada Gambar 1.

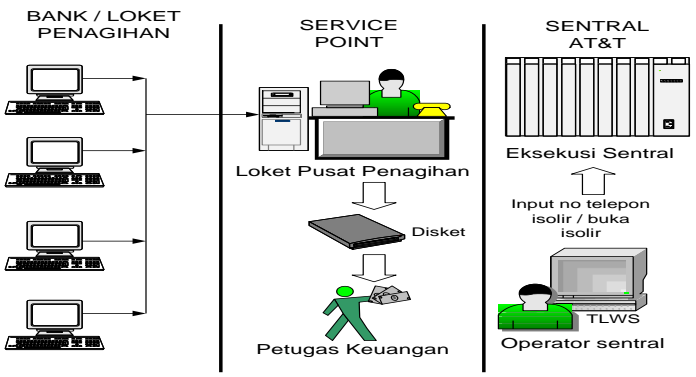

Gambar 1. Proses Isolasi Secara Manual

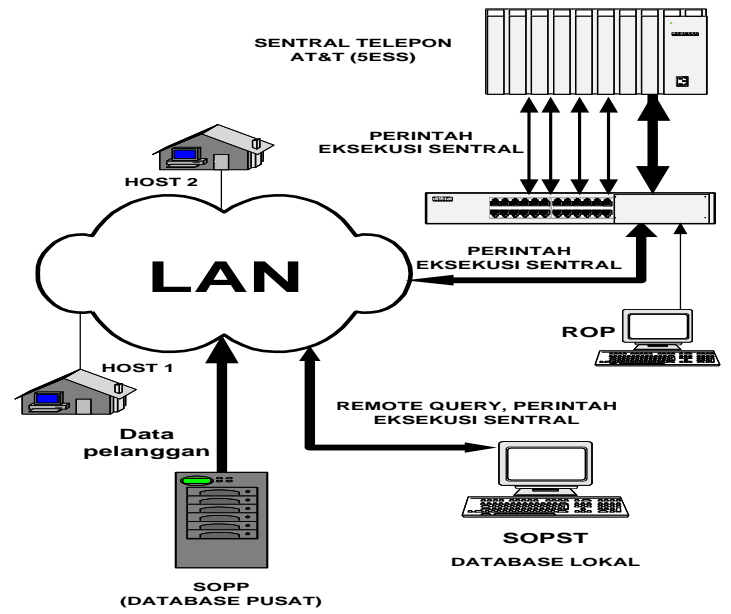

Gambar 2. Sistem Isolasi Dan Buka Isolasi

\subsection{Tujuan Pembangunan Sistem}

Merujuk pada beberapa kelemahan yang terdapat pada sistem manual, maka dibangun sistem yang memiliki kemampuan:

a. Mem-bypass semua proses manual yang ada di sistem lama dan menggantikannya dengan mekanisme yang terkomputerisasi. Hal ini untuk meminimalkan terjadinya human error pada operasional pengisolasian sentral.

b. Bekerja sesuai dengan jadwal yang ditentukan, misal : proses isolasi tiap jam tertentu pada akhir bulan, sementara proses buka isolasi dilakukan setiap dua jam tiap hari.

c. Menangani kesalahan yang mungkin terjadi berkaitan dengan perangkat sentral maupun jaringan, sehingga dapat menjamin integritas data dan status pelanggan.

d. Memberikan laporan tentang status dan data operasi isolasi maupun buka isolasi yang dilakukan oleh sentral.

Deskripsi sistem yang dikembangkan diilustrasikan pada Gambar 2.

\subsection{Perancangan Sistem}

Sistem akan diaktifkan oleh scheduler yang terdapat pada sistem operasi. Pengaktifan ini tergantung dari jadwal yang sebelumnya telah dispesifikasikan untuk tiap proses (isolasi dan buka isolasi). Ketika diaktifkan, sistem akan menghubungi SOPP (Sistem Online Payment Point) untuk mendapatkan daftar nomor telepon yang harus diubah status isolasinya. Selanjutnya akan dikirimkan perintah ke sentral sesuai dengan perubahan status isolasi untuk setiap nomor telepon dalam daftar dari SOPP. Jika sistem sedang tidak mengeksekusi perintah ke sentral, pengguna dapat memberikan query untuk meminta sajian laporan. Diagram konteks sistem SOPST terlihat pada Gambar 3 dan di-break-down pada Gambar 4 dan 5.

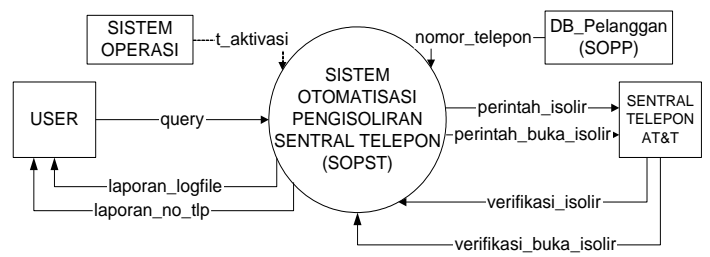

Gambar 3. Diagram Konteks SOPST

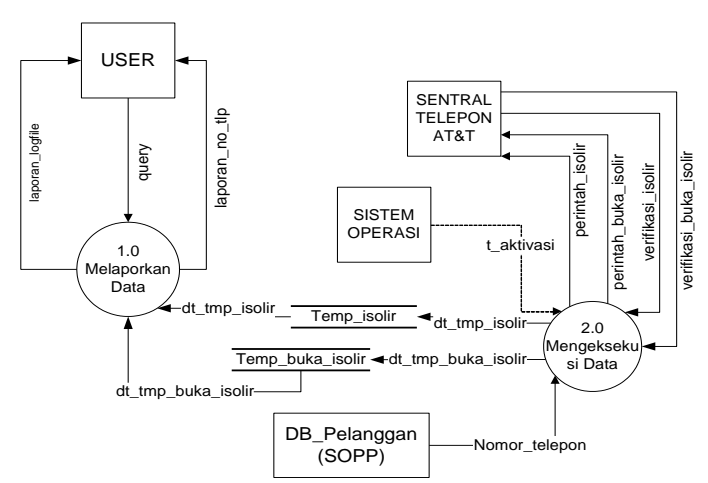

Gambar 4. DFD Level 1

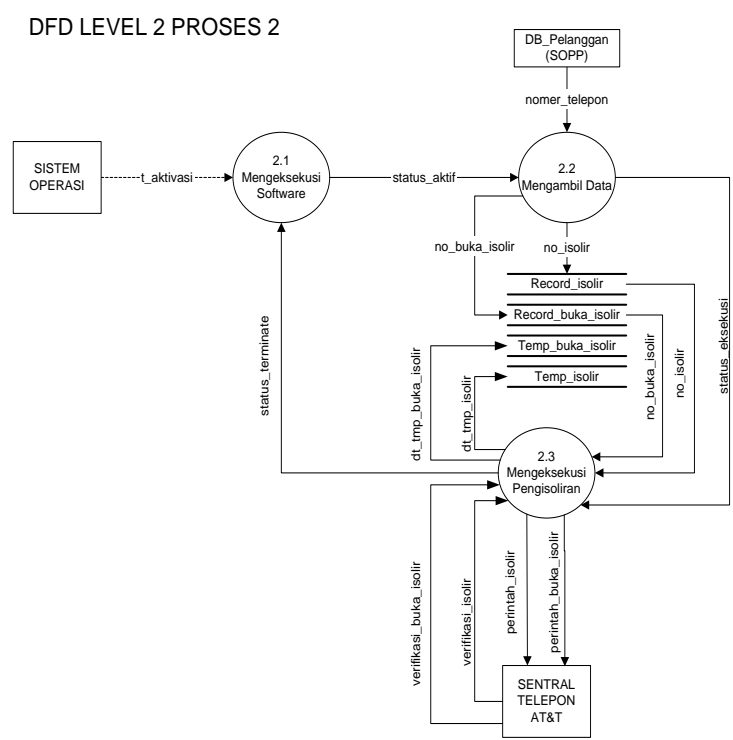

Gambar 5. DFD Level 2 proses 2 
Beberapa hal yang perlu dicatat dalam rancangan ini :

a. Untuk kasus salah eksekusi (error pada sentral), sistem akan mengulangi perintah yang gagal tersebut setelah seluruh nomor dicoba untuk dieksekusi.

b. Pengeksekusian dilakukan sampai record terakhir tanpa bisa di-interupt di tengah proses.

c. Sub sistem client memiliki database lokal yang harus terus dipantau dan diremajakan (setelah terlebih dahulu di-backup)

Berikut adalah penjelasan mengenai sejumlah tabel yang terlibat dalam sistem, yakni :

a. db_pelanggan : berupa file berekstensi *.txt yang telah disiapkan oleh SOPP dan didapat melalui proses FTP ke server SOPP. Datanya dinamis, sesuai dengan data pelunasan/penunggakan pembayaran dari bagian keuangan.

b. Tabel record_isolasi dan record_buka_isolasi merupakan tabel transaksi yang isinya selalu berubah setiap dilakukan pengambilan data baru ke database SOPP. Setiap kali ada data baru dari SOPP, kedua tabel ini akan dikosongkan terlebih dahulu. Masing-masing terdiri dari field nomor telepon dan status eksekusi. Record yang telah berhasil dieksekusi akan dihapus.

c. Tabel temp_isolasi dan temp_buka_isolasi adalah tabel log yang memuat semua status eksekusi isolasi maupun buka isolasi pada sentral. Terdiri dari field nomor telepon, status eksekusi dan waktu eksekusi.

d. Tabel Tcommand berisi perintah-perintah yang berkaitan dengan isolasi dan buka isolasi pada sentral. Terdiri dari field Id, head_command dan tail_command.

\section{Implementasi dan Evaluasi}

\subsection{Penulisan Kode dan Pengujian Program}

Pengkodean dan pengujian dilakukan dengan langkah-langkah sebagai berikut :

a. Transformasi perancangan database ke basisdata fisik, sementara ini dari MS-Access 2000.

b. Membuat kode program dengan menggunakan Borland Delphi 6.

c. Pengujian program dengan menguji tiap modul. Pengujian dilakukan dengan dua skenario :

a. Pengujian menggunakan simulator sentral dan SOPP pada sistem operasi Linux Red Hat 7.2.

b. Pengujian secara langsung ke sentral (kasus: sentral AT\&T STO Cimahi).

\subsection{Evaluasi}

\subsubsection{Response Time}

Pengujian response time terutama dilakukan untuk pra-eksekusi sentral, yaitu proses ambil data dan pengolahan sampai siap dieksekusi ke sentral. Eksekusi oleh sentral sendiri, antara SOPST dengan sistem lama yang digunakan PT Telkom memiliki respons time rata-rata yang sama, yakni 0.5 second untuk setiap perintah isolasi atau buka isolasi.

Pengujian dilakukan dalam rentang waktu dua bulan, Juli dan Agustus 2003, dengan mengamati waktu yang dibutuhkan sistem manual untuk mengeksekusi proses isolasi, kemudian pada saat yang sama dibandingkan dengan waktu yang dibutuhkan oleh SOPST. Karena masing-masing hanya dilakukan terhadap data nomor telepon di STO Cimahi, maka untuk mendapatkan gambaran kasar waktu total yang dibutuhkan untuk tiga belas STO di seluruh Bandung, nilai tadi dikalikan 13. Untuk seluruh STO di Bandung, sistem manual membutuhkan waktu 372,783 menit, sementara SOPST membutuhkan waktu hanya 11,1583 menit.

Efektivitas waktu

$$
\begin{aligned}
& =\left(\left(\mathrm{T}_{\text {rata manual }}-\mathrm{T}_{\text {rata SOPST }}\right) /\left(\mathrm{T}_{\text {rata manaul }}\right)\right) \times 100 \% \\
& =((372,783-11,1583) / 372,783) \times 100 \% \\
& \approx \mathbf{9 7 \%}
\end{aligned}
$$

Data pengukuran waktu proses secara manual dan menggunakan SOPST dapat dilihat pada lampiran.

\subsubsection{Reliabilitas}

Jika terdapat nomor yang belum tereksekusi dengan sukses maka SOPST akan mengeksekusinya kembali secara round-robin. Faktor kesalahan perintah isolasi pun dapat dihilangkan, sebab semua perintah telah dimasukkan dalam database. Selain itu, SOPST mampu menangani masalah :

a) Error di jaringan dan SOPP saat tiba waktu eksekusi isolasi atau buka isolasi.

b) Error sebelum mengeksekusi nomor telepon (sentral down atau jaringan putus).

c) Error saat di awal, tengah, atau akhir proses eksekusi (jaringan putus)

Aplikasi SOPST menggunakan algoritma khusus untuk penanganan kasus-kasus error di atas, yaitu :

\section{Setiap 10 detik dilakukan \\ If CekJaringan(HostSentralAT\& $\mathrm{T}$ = true then \\ (CekNomorGagal(TabelTransaksiAT\&T) \\ If (RecordCount(TabelTransaksiAT\&T) $>0$ ) and (PernahPutus) then \\ Otomatis(TelnetAT\&T) // mengeksekusi nomor dari record pertama pada TabelTransaksiAT\& T \\ Keterangan: \\ CekJaringan : Prosedur untuk mencek kondisi jaringan ke sentral. \\ Otomatis : Prosedur menjalankan perintah pengisolasian secara sekuensial.}

Tabel Transaksi up to date, record dihapus jika sukses tereksekusi, jika gagal diberi flag status "G".

\subsubsection{Ketepatan waktu}

Dengan sistem terkomputerisasi, selama tidak ada force majeure, dapat dijamin sistem akan melakukan proses isolasi tiap akhir bulan dan melakukan proses buka isolasi tiap dua jam sekali, tanpa campur tangan dari operator. Pengaktifan proses dengan memanfaatkan scheduler yang 
dimiliki oleh sistem operasi menuntut pengaturan secara manual yang tepat oleh administrator.

\subsubsection{Fleksibilitas}

Fleksibilitas SOPST dapat dilihat pada setting aplikasi antara lain:

a) Setting SOPP: direktori target file, nama file isolasi dan buka isolasi di server SOPP dapat ditentukan berdasarkan STO serta pengubahan atau penambahan prefik number untuk sentral yang bersangkutan.

b) Setting sentral: terdapat menu tambahan jika sebuah STO terdapat 2 tipe sentral digital yaitu AT\&T dan EWSD.

c) Perintah isolasi dan buka isolasi disimpan pada database sehingga dapat disesuaikan dengan sentral yang digunakan.

\subsubsection{Reporting}

Laporan SOPST dapat diminta oleh operator setiap kali eksekusi sentral selesai, dengan memuat informasi mengenai berapa nomor yang tereksekusi dan berapa nomor yang pernah gagal dieksekusi.

\section{Kesimpulan dan Saran}

Hal-hal yang dapat disimpulkan antara lain:

1. Sistem yang dibangun (SOPST) telah mampu menggantikan sistem manual dalam melakukan eksekusi isolasi dan buka isolasi dengan jaminan ketepatan waktu.

2. Dari segi response time, SOPST menunjukkan efisiensi waktu eksekusi sampai dengan 97\%, dibandingkan terhadap sistem manual yang digunakan oleh PT Telkom selama ini.

3. Dari segi fleksibilitas, seting SOPP dan sentral dapat dikonfigurasi secara dinamis dari dalam aplikasi. SOPST bahkan menyediakan fasilitas untuk dapat diimplementasikan pada STO yang berbeda dengan konfigurasi dan type sentral digital AT\&T dan EWSD.

4. Dari segi reliabilitas, tanpa mengikutkan faktor force majeure, SOPST menjamin eksekusi isolasi dan buka isolasi dengan error $0 \%$.

5. Operator dapat memperoleh informasi yang jelas dan real time mengenai status proses isolasi dan buka isolasi.

Untuk pengembangan lanjut, selain yang telah diujikan pada perangkat sentral AT\&T 5ESS, sebenarnya sistem SOPST juga memuat fasilitas untuk sentral EWSD. Akan lebih baik jika SOPST ini bersifat modular. Fungsi komunikasi dengan setiap jenis sentral dibangun dalam bentuk modul. Sehingga setiap STO dapat memasang modul sentral pada SOPST yang sesuai dengan tipe sentral yang dimilikinya.

\section{Daftar Pustaka}

[1] Kustian, Hendri, 1994, Petunjuk Operasi dan Pemeliharaan Sentral Telepon Digital Indonesia 5ESS, Bandung: PT Telekomunikasi.

[2] Lucent Technology, 1999, Lucent Technology 5ESS-2000 Switch Internasional Online Documentation System, USA: Bell Labs Innovations.

[3] Pressman, Roger, 1997, Software Engineering: A Practitioner's Approach Fourth Edition, New York: Mc Graw-Hill.

[4] Rahman, Murzeki, 2000, Aplikasi Program EDTS Sentral EWSD Untuk Pengisolasian Tunggakan Dengan Disket Data Loket Penagihan, Bandung: STT Telkom.

[5] _ _ 1994, Sistem Deskription 5ESS, Bandung: Kandatel Bandung.

[6] _ 2001, Perhitungan Beban Prosesor Untuk Sentral 5ESS di STO Cimahi, Bandung: STT Telkom.

\section{Lampiran}

\section{Data Pengukuran Response Time}

Tabel 1. Pra-Eksekusi Sentral Secara Manual

\begin{tabular}{|l|c|c|c|c|}
\hline \multirow{2}{*}{ Aksi } & \multicolumn{2}{|c|}{ Juli 2003 } & \multicolumn{2}{c|}{ Agustus 2003 } \\
\cline { 2 - 5 } & T_awal & T_akhir & T_awal & T_akhir \\
\hline sorting data untuk usul isolasi & $20: 14: 46$ & $20: 24: 36$ & $21: 09: 40$ & $21: 19: 15$ \\
\hline Load data usul isolasi untuk diisolasi & $20: 29: 21$ & $20: 34: 27$ & $21: 19: 32$ & $21: 33: 50$ \\
\hline cetak data usul isolasi & $20: 35: 01$ & $20: 36: 11$ & $21: 41: 08$ & $21: 41: 27$ \\
\hline Ambil data dan sorting & $20: 41: 13$ & $20: 51: 16$ & $21: 46: 57$ & $22: 06: 33$ \\
\hline validasi, komparasi per STO & $20: 52: 19$ & $21: 11: 21$ & $21: 57: 01$ & $22: 16: 20$ \\
\hline Pengecekan nomor & $21: 18: 30$ & $21: 36: 31$ & $22: 23: 15$ & $22: 41: 17$ \\
\hline kirim data ke operator di sentral & $21: 38: 55$ & $21: 59: 16$ & $22: 42: 55$ & $23: 03: 10$ \\
\hline pengecekan data sampling & $22: 00: 00$ & $22: 14: 00$ & $23: 05: 00$ & $23: 20: 00$ \\
\hline transfer data ke sentral \{fisik\} & $22: 15: 00$ & $02: 20: 00$ & $23: 21: 00$ & $03: 25: 00$ \\
\hline Penjalanan ratelsi untuk buka isolasi & $03: 00: 00$ & & $03: 30: 00$ \\
\hline Total waktu (jam:menit:detik) & $6: 05: 14$ & \multicolumn{3}{c|}{$6: 20: 20$} \\
\hline Jumlah Nomor Telepon Diproses & \multicolumn{2}{|c|}{34.825} & \multicolumn{3}{c|}{34.674} \\
\hline
\end{tabular}

Tabel 2. Pra-Eksekusi Sentral Dengan SOPST

\begin{tabular}{|c|c|c|}
\hline \multirow[b]{2}{*}{ Aksi } & $01 / 07 / 2003$ & $01 / 08 / 2003$ \\
\hline & $\begin{array}{l}\text { Di-eksekusi } \\
\text { pada Pukul }\end{array}$ & $\begin{array}{l}\text { Di-eksekusi } \\
\text { pada Pukul }\end{array}$ \\
\hline Connecting to 10.14 .201 .25 & 20:00:00 & 20:00:00 \\
\hline Connected & 20:00:00 & 20:00:00 \\
\hline$== \pm=$ Proses connect ke SOPP berhasil ===I & $20: 00: 00$ & $20: 00: 00$ \\
\hline Data berhasil diambil & $20: 00: 00$ & $20: 00: 00$ \\
\hline Disconnecting from 10.14.201.25 & $20: 00: 00$ & $20: 00: 00$ \\
\hline Not connected & $20: 00: 00$ & $20: 00: 00$ \\
\hline Connecting to 10.14 .201 .25 & $20: 00: 52$ & $20: 00: 51$ \\
\hline Connected & 20:00:52 & 20:00:51 \\
\hline Total waktu & 52 detik & 51 detik \\
\hline Jumlah Nomor Telepon Yang Diproses & 3.236 & 3.514 \\
\hline
\end{tabular}

